\title{
Financial Stress Testing of Real Estate Enterprise
}

\author{
Yao Long \\ School of Business Administrations \\ Sichuan University \\ Chengdu, China
}

\begin{abstract}
In this paper, we choose "Stress Testing", which is widely used in the financial field, to analyze the risk pressure of the real estate industry. The real estate industry's pressure factors are divided into internal and external factors. Internal factors mainly reflect the enterprise inventory turnover, liquidity and solvency; the external factors are mainly macroeconomic data indicators. The study found that inventory turnover rate and quick ratio have impact on the real estate business cash flow; both respectively represent the liquidity pressure and debt service pressure. In the external factors, the loan interest rate and the real estate industry boom index have influence on inventory turnover rate and quick ratio. Hence, it can be concluded: Real estate enterprises have liquidity pressure and debt service pressure, and the external macroeconomic factors, such as loan interest rates and real estate industry boom index, indirectly affect the real estate business operation.
\end{abstract}

Keywords—real estate enterprise; financial pressure; stress testing

\section{INTRODUCTION}

The real estate industry is the pillar industry of the national economy, and its healthy development is the guarantee of the steady improvement of the national economy. Because of the policy orientation of the real estate industry, it is vulnerable to the impact of macroeconomic policies, and the real estate enterprise itself has high inventory, low liquidity and financing difficulties and other aspects of pressure. Stress testing, as a quantitative analysis based risk management tool, can effectively reflect the stability of the portfolio of financial institutions under the pressure of changes in key market variables, and is widely used in financial institutions. In view of the close connection between the real estate enterprises and the banking industry, the two have similar external environment, and it is feasible to introduce the stress test into the real estate industry. The purpose of this paper is to test the financial pressure of real estate enterprises, and analyze the financial pressure of the real estate industry.

The idea of applying stress testing to real estate enterprises has been proposed by domestic scholars in recent years, but there are few literatures about it. Most of the documents related to real estate enterprises are about the risks faced by real estate (such as investment risk, financial risk, project risk, financial risk, etc.), financial crisis warning and so on. At present, there is no pressure test applied in the real estate industry in foreign literature. Foreign scholars mainly use model and index to measure all kinds of risks that real estate faces, and construct the real estate enterprise financial crisis forewarning model. In the risk analysis of real estate enterprises, Crocker H. Liu (1994) combines the present value model with the VAR model to decompose the investment risk of real estate enterprises. Some scholars use the Monte Carlo simulation method and fuzzy comprehensive evaluation method to analyze the cash flow of listed real estate enterprises, and evaluate the financial risk of listed Real Estate Company (Yu-jie Sang, 2012; Zhang Minli, 2012). In the aspect of crisis early warning, Miglani S (2005) takes Australian listed companies' data for five years as the sample to analyze the role of corporate governance mechanism in reducing the financial crisis of enterprises. Yang Li (2013) analyzes the annual financial statements data of listed real estate enterprises, and establishes the financial crisis early warning model of the real estate industry listed companies by using the $\mathrm{Z}$ value benchmark model.

The domestic research on the various risks faced by real estate and the real estate enterprise financial crisis early warning model are as follows. In the risk analysis of real estate enterprises, scholars use genetic algorithm, AHP method, Monte Carlo statistical simulation method, multilevel fuzzy model to evaluate investment risk. (Kuang, 2006; Jiang, 2007; Yang, 2008; Liu, 2009). In the aspect of crisis early warning, the existing literature mainly uses principal component analysis and Logistic regression to analyze the financial indicators of listed Real Estate Company, and constructs the financial early warning model (Chen, 2010; Zhang, 2012). This kind of literature analyzes the risks faced by real estate enterprises, and puts forward a feasible method to measure risks. The financial early warning model is constructed, which plays a role in preventing and warning the financial crisis of real estate enterprises.

According to the existing literature, most of the existing researches at home and abroad are related to the measurement of real estate risks and the construction of real estate financial crisis warning model. This kind of literature analyzes the risks faced by real estate enterprises, puts forward feasible methods to measure risks, and constructs a financial early warning model, which plays a role in preventing and warning the financial crisis of real estate enterprises. There is a certain correlation between the research content and the financial pressure of real estate enterprises, but it is different from the financial stress test. At present, there is a small amount of the real estate enterprise pressure test of the domestic literature, but this kind of 
literature on the real estate enterprises use pressure test, study the macroeconomic factors of the real estate industry pressure, but the results are too indirect, not directly from the analysis of the real estate business pressure, ignore the internal factors of the real the real estate business pressure, so the analysis results not convincing enough.

\section{DATA}

\section{A. Model Setup}

This paper selects 150 listed real estate enterprises in Shanghai and Shenzhen Stock Exchange as the sample of regression analysis of real estate enterprises. The listed real estate enterprises with special treatment or incomplete data were deleted. The financial and macroeconomic quarterly data ranged from 2003 to 2015 . The data in this paper comes from the CSMAR database. SPSS Statistics17.0 data analysis software is used.

In this paper, Logistic regression model is selected as the model of stress test. Logistic regression model is a linear probability model, which is widely used in commercial banks to test the volatility of bank asset portfolio. When using Logistic regression model for regression analysis, we first need to convert continuous dependent variables into two categorical variables. Taking the median value of the continuous dependent variable as the critical value, the condition less than the critical value is taken as 0 , and the value is greater than the critical value, taking 1 .

$$
p_{i}=\frac{1}{1+e^{-\left(\alpha+\beta x_{i}\right)}}
$$

$\mathrm{P}_{\mathrm{i}}$ is the probability of occurrence, $\mathrm{x}_{\mathrm{i}}$ is independent variable, and ${ }^{\alpha}$ and $\beta$ are regression intercept and regression coefficient respectively. Converting Logistic regression model into Logit form

$$
\ln \left(\frac{p_{i}}{1-p_{i}}\right)=\alpha+\beta x_{i}
$$

Logit $(\mathrm{P})$ will be used to refer to $(2)$

\section{B. Select Variables}

\begin{tabular}{|c|c|c|c|}
\hline \multicolumn{2}{|r|}{ Type of variable } & Variable symbol & Variable definition \\
\hline \multirow{3}{*}{ Internal factors } & Operating profit margin & $\mathrm{X} 1$ & Ratio of operating profit to operating income \\
\hline & Inventory turnover & $\mathrm{X} 2$ & $\begin{array}{l}\text { The ratio of cost of goods sold and the average inventory balance in a } \\
\text { certain period of time }\end{array}$ \\
\hline & Quick ratio & $\mathrm{X} 3$ & Ratio of enterprise's quick assets to current liabilities \\
\hline \multirow{4}{*}{ External factors } & GDP growth rate & $\mathrm{Z1}$ & $\begin{array}{l}\text { The growth rate of the market value of all final products and services } \\
\text { produced by all resident units of a country in a certain period of time }\end{array}$ \\
\hline & Five-year lending rate & $\mathrm{Z2}$ & The loan interest rate of 5 years or more \\
\hline & Real estate boom index & $\mathrm{Z3}$ & The overall index of the real estate development boom \\
\hline & $\begin{array}{l}\text { Investment in } \\
\text { development }\end{array}$ & $\mathrm{Z4}$ & $\begin{array}{l}\mathrm{n} \text { a certain period of time the whole society construction and purchase of } \\
\text { fixed assets in real estate development workload and related costs in the } \\
\text { form of money }\end{array}$ \\
\hline Dependent variable & $\begin{array}{l}\text { Net cash flows from operating } \\
\text { activities }\end{array}$ & $\mathrm{Y}$ & $\begin{array}{l}\text { Net increase in cash and cash equivalents subtract net cash flows from } \\
\text { financing and investing activities }\end{array}$ \\
\hline
\end{tabular}

TABLE I. VARIABLE TABLE

\section{EMPIRICAL FINDINGS}

\section{A. Internal Pressure Factors}

The median -12499607.63 of operating cash flow net (Y) is the critical point. Convert the net cash flow from operating activities (Y) into two categorical variables and import dependent variables: net operating cash flow (Y) and internal variables: operating profit rate (X1), inventory turnover rate
(X2), quick ratio (X3) into statistical software. Variable entry method chooses backward LR sieve division, excluding variables according to the probability value of maximum likelihood estimation statistics. Since the method of entry is stepwise regression, the regression process will automatically delete a common linear independent variable, so there is no multicollinearity problem in the final regression results. The regression results are in "Table II":

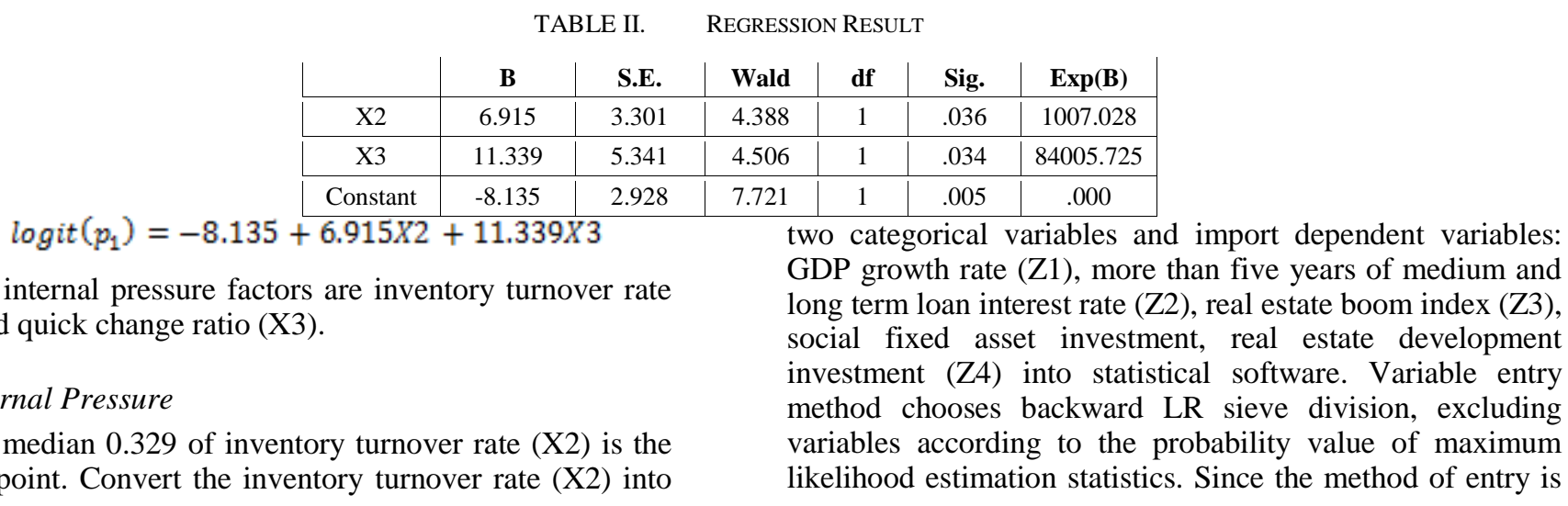


stepwise regression, the regression process will automatically delete a common linear independent variable, so there is no multicollinearity problem in the final regression results. The regression results are as in "Table III":

TABLE III. REGRESSION RESULT

\begin{tabular}{|c|c|c|c|c|c|c|}
\hline Z2 & $\begin{array}{r}\mathbf{B} \\
-.918\end{array}$ & \begin{tabular}{|l} 
S.E. \\
.525
\end{tabular} & \begin{tabular}{|l} 
Wald \\
3.057
\end{tabular} & ${ }_{1} \mathbf{d f}$ & $\begin{array}{l}\text { Sig. } \\
.008\end{array}$ & $\begin{array}{l}\operatorname{Exp}(\mathbf{B}) \\
.399\end{array}$ \\
\hline Z3 & .128 & .041 & 9.601 & 1 & .002 & 1.137 \\
\hline Constant & -10.934 & 5.075 & 4.643 & 1 & .031 & .000 \\
\hline
\end{tabular}

The external pressure factors affecting inventory turnover are more than five years long and medium term loan interest rate $(\mathrm{Z} 2)$ and real estate boom index $(\mathrm{Z} 3)$.

The median 0.574 of quick change ratio (X3) is the critical point. Convert the quick change ratio (X3) into two categorical variables and import dependent variables: GDP growth rate $(\mathrm{Z} 1)$, more than five years of medium and long term loan interest rate (Z2), real estate boom index (Z3), social fixed asset investment, real estate development investment (Z4) into statistical software. Variable entry method chooses backward LR sieve division, excluding variables according to the probability value of maximum likelihood estimation statistics. Since the method of entry is stepwise regression, the regression process will automatically delete a common linear independent variable, so there is no multicollinearity problem in the final regression results. The regression results are in "Table IV":

TABLE IV. REGRESSION RESULT

\begin{tabular}{|l|l|l|l|l|l|l|} 
& \multicolumn{1}{|c|}{ B } & \multicolumn{1}{c|}{ S.E. } & \multicolumn{1}{c|}{ Wald } & df & Sig. & \multicolumn{1}{|c|}{$\operatorname{Exp(B)}$} \\
\hline$Z 2$ & -3.115 & 1.331 & 5.476 & 1 & .019 & .044 \\
\hline$Z 3$ & .537 & .183 & 8.600 & 1 & .003 & 1.710 \\
\hline Constant & -47.256 & 16.843 & 7.872 & 1 & .005 & .000 \\
\hline \multicolumn{2}{r|}{ logit $\left(p_{a}\right)=-47.256-3.115 Z 2+0.537 Z 3$}
\end{tabular}

The external pressure factors affecting quick change ratio are more than five years long and medium term loan interest rate $(\mathrm{Z} 2)$ and real estate boom index $(\mathrm{Z} 3)$.

\section{CONCLUSION}

This paper tries to apply stress testing to the real estate enterprises to analyze the financial pressure. The test results are as follows: cash flow is positively correlated with inventory turnover and quick ratio. Inventory turnover and quick ratio are negatively correlated with long-term loan interest rate. Inventory turnover and quick ratio are positively correlated with real estate industry prosperity index. The test results show that the real estate enterprises do have the pressure of liquidity pressure and short-term debt repayment, which has a greater impact on the cash flow of the enterprise. At the same time, the external macroeconomic environment will also affect the cash abortion of enterprises indirectly. Stress testing can reflect the relationship between macroeconomic factors and internal risk factors of real estate enterprises, and can predict the ability of cash flow of enterprises to withstand the risk of internal risk changes. It has a certain reference function to the real estate enterprise to carry on the investment and the government to publish the macro policy about the real estate.

\section{REFERENCES}

[1] Crocker H. Liu, Mei Jianping. An analysis of real-estate risk using the present value model $[\mathrm{J}]$. The Journal of Real Estate Finance and Economics, 1994,81:

[2] Sang Yujie. Evaluation on Operational Cash Flow at Risk for China's Real Estate Listed Companies in the Event Window of Financial Crisis[J]. Advances in Electronic Engineering, Communication and Management,2012,01:

[3] ZhangML(ZhangMinli), YangWp(Yang Wenpo). Fuzzy Comprehensive Evaluation Method Applied in the Real Estate Investment Risks Research[J]. Physics Procedia,2012,24:

[4] Miglani S, Ahmed K, Henry D. Voluntary corporate governance structure and financial distress: Evidence from Australia[J]. Journal of Contemporary Accounting \& Economics, 2015, 11(1):18-30.

[5] Yang Li. Financial Distress Early Warning Model for Listed Real Estate Companies of China Based on Multiple Discriminant Analysis[C]. Proceedings of the 17th International Symposium on Advancement of Construction Management and Real Estate.pp 11531161 